\title{
Exploring the impact of economic and sociopolitical development on people's health and well-being: A case study of the Karanga people in Masvingo, Zimbabwe
}

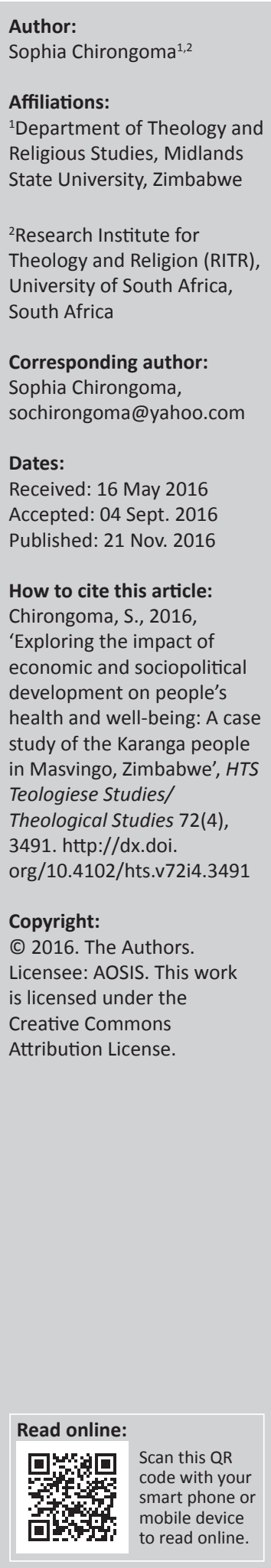

\begin{abstract}
Through an exploration of the collapse of the Zimbabwean health delivery systems during the period 2000-2010, this article examines the Karanga people's indigenous responses to utano (health and well-being). The first section explores the impact of Zimbabwe's economic and sociopolitical development on people's health and well-being. The next section foregrounds the 'agency' of the Karanga community in accessing and facilitating health care, especially their utilisation of multiple healthcare providers as well as providing health care through indigenous remedies such as traditional medicine and faith-healing. In line with the Sustainable Development Goals (SDGs), particularly SDG 3 which aspires to ensure healthy lives and promote well-being for all at all ages, the concluding section offers insights for developing an indigenous Karanga theology of utano utilising communal resources and illustrating that the concept of 'development' should not be confined to rigid Western development perspectives.
\end{abstract}

\section{Introduction}

For most African people, health and well-being are fundamental issues, which are integral to their lived realities. To the traditional African, no illness or misfortune happens through sheer coincidence. Everything happens for a reason and requires an explanation that can only be adequately provided by the traditional diviner. ${ }^{1}$ This attitude is embedded in the African understanding of human existence, which is viewed as a communal form of existence. This perspective is also influenced by the African understanding of life. According to Manda (2006:39), '[1]ife is regarded as a sacred gift from God; hence, the affirmation of life is central in African societies and all forms of life must be promoted and preserved'. This is also reiterated by JeanMarc Ela who argues that 'an analysis of the socio-economic indicators of health in Africa reveals the mechanisms that enclose humanity in a circle of misery and sickness' (1989:67). According to Ela (1989), research has established that health concerns are a top priority for most Africans. He argues that more and more Africans prioritise their health and well-being ahead of their families and job security. Writing particularly about the Karanga people, Tabona Shoko (2007:35) concurs with Ela by stating that ' $[\mathrm{t}]$ he Karanga enjoy peace of mind when their state of health is in good condition. Health involves physical and spiritual states. Absence of illness and disease brings relief and joy ...'. Shoko (2007) proceeds to explicate that:

... the Karanga are preoccupied with the desire to preserve health and well-being ... and to restore it when
a breakdown in general fortune occurs in a world that is potentially dangerous and populated by forces
of evil. (p. 139)

If health and well-being (utano) is a priority for most Africans, the almost complete breakdown of the Zimbabwean public healthcare system in the last two decades (1990-2010) has had far-reaching repercussions on the whole populace. Using field work, this article seeks to establish the agency of the community in responding to the national healthcare crisis, focusing specially on the Karanga community in Masvingo province, particularly Murinye district of Zimbabwe. The article contributes to wider discussions around health agency and health assets stimulated by the African Religious Health Assets Programme (ARHAP). ${ }^{2}$ With African researchers and practitioners at the centre, 1.The traditional diviner is known as n'anga among the Karanga-Shona in Zimbabwe.

2.The author is aware that in 2012, ARHAP changed its name to IRHAP (International Religious Assets Programme) in order to more properly reflect the expansion of its interests and partners. However, throughout this study, reference will be made to the term ARHAP because the study commenced during the time when it was still ARHAP.

Note: This article draws insights from the author's unpublished doctoral thesis entitled, 'Navigating Indigenous Resources That Can Be Utilised in Constructing a Karanga Theology of Health and Well being (Utano): An Exploration of Health Agency in Contemporary Zimbabwe' submitted to the University of KwaZulu Natal, November, 2013.

This article forms part of the special collection on 'Engaging development: Contributions to a critical theological and religious debate' in HTS Teologiese Studies/Theological Studies Volume 72, Issue 4, 2016. 
ARHAP seeks to 'develop a systematic knowledge base of religious health assets (RHAs) in sub-Saharan Africa' (see ARHAP 2006; de Gruchy 2003; Gunderson 1998; Kretzmann \& McKnight 1993, 2002). ARHAP (2006) also endeavours to assist in:

aligning and enhancing the work of both religious health leaders and public policy-makers in their collaborative effort to meet the challenges caused by diseases, such as HIV and AIDS; and hence to promote sustainable health, especially for those who live in poverty or under marginal conditions. (n.p)

It reiterates that these interface and complexity should be embodied in policies and practices that generate an alignment of best practices between health systems and religious bodies, initiatives and institutions. ARHAP sees this approach as 'both a strategic and a development imperative for public health systems if health interventions are to be sustainably and deeply embedded in local communities' (Thomas et al. 2006).

Building on the research undertaken by ARHAP, this article highlights the need for policy-makers in Zimbabwe's public healthcare system to adopt the approach suggested by ARHAP scholars and incorporate local communities' perceptions of health and well-being and their responses to ill-health. With a particular focus on Karanga healthworlds (utano), this article affirms the following assertions made by ARHAP:

Health seekers in an African context more often than not work with and live out of a conception of the body that is not limited to the physical individual entity ... This has a direct impact, then, on how people seek health, what they will regard as 'more healthy' (it may be that their individual body takes second place to what they perceive as the health of the family or community, for example), and how they respond to interventions by others. (Thomas et al. 2006:19)

This article therefore foregrounds the agency of the Karanga community in accessing and facilitating health care in Zimbabwe. It highlights that the Karanga people are not just passive recipients of medical care, but they are also active participants in seeking health care, especially their utilisation of multiple healthcare providers and their provision of health care through indigenous remedies such as traditional medicine and faith-healing as well as the modern healthcare system.

\section{Research methodology}

Utilising literature analysis, this article explores the African understanding of health and well-being ('healthworlds') generally speaking but also more specifically in terms of the Karanga understanding of well-being. The article also draws insights from oral theology. Oral theology is primarily theology done from below and 'refers to the varied religious expressions of an oral community based on their underlying faith experiences' (Naudé 1996:23). In the words of Anthony Casey (2011):
Oral theology is first developed from an emic perspective while systematic theology is done from an etic perspective. Oral theology is applied context based, and answers the most important questions about life in that culture. (n.p.)

This article utilises the emic perspective whereby the research participants are the key sources of information regarding their understanding of health and well-being. This therefore implies that the exploration of Karanga health-seeking strategies and healthcare provision is based on the expositions provided by the participants' lived realities gathered through interviews and participant observation.

The author conducted fieldwork in the Murinye District in Masvingo, Zimbabwe, which was to ascertain the Karanga conception of utano ('health and well-being') and also to establish ways in which people responded to the healthcare crisis (agency), particularly their utilisation of multiple healthcare providers as well as providing health care in terms of indigenous remedies such as traditional medicine and faith-healing. Semi-structured interviews were conducted among health seekers and healthcare providers. The participants were selected through the use of the snowballing sampling technique.

The study participant sample was as follows: The healthcare providers were divided into three categories: biomedical practitioners (represented by nurses from the two local clinics, the Mashenjere and Shonganiso clinics), faith or prophet healers (represented by healing prophets within the Pentecostal fold who rely on the healing power of the Holy Spirit) and traditional healers (represented by indigenous healers who make use of traditional medicine or herbs and rely on ancestral resources). There were five respondents from each category, that is, interviews were conducted with five biomedical practitioners; five nurses and five prophet healers based in Murinye District in Masvingo, highlighting how health-seekers are navigating these three systems (modern medical system; faith-healing and traditional healing systems). Information was drawn through semistructured interviews with key informants as well as participant observation during healing rituals. During the healing rituals, information was gathered from both healthseekers and healthcare providers.

Both health-seekers and healthcare providers were asked questions regarding their personal health-seeking behaviour and their communities' health-seeking behaviour, that is, whether they rely on only one healthcare provider or whether they sometimes utilise two or three healthcare systems simultaneously and why that would be the case? Information gathered from the case studies conducted revealed that most health-seekers utilise multiple healthcare providers and all the healthcare providers interviewed expressed openness to the interchangeable use of the three healthcare systems. ${ }^{3}$

3.Depending on the nature of the illiness or at times the availability of health facilities providers, some patients utilize all the three facilities concurrently; for example, a providers, some patients utilize all the three facilities concurrently; for example, a
patient can first seek health care at the clinic and from there visit either the faithhealers or traditional healers and in other cases consult both. 
The fieldwork research also explored the Karanga indigenous notions of well-being, showing that for Karanga, religion and health are closely related as illustrated by the case studies whereby the prophets who are regarded as healers are blending indigenous traditions and Christian concepts in their healing ministry.

A life history approach was employed to establish trends and patterns in the Karanga peoples' utilisation of the three medical systems. Dhunpath and Samuel (2009) explain this approach as follows:

Life history research captures 'lives as experienced'. It provides the qualitative interpretation individuals make of their lived circumstances and events. It shows how individuals make meaning of their lives. Its interpretivist and phenomenological roots are evident. (p. $x$ )

In particular, the life history approach places emphasis on indepth analyses of the life histories of research participants to appreciate the challenges and opportunities available to individuals and families (Samuel 2009). As Kakuru and Paradza (2007) highlight, this is a very helpful approach as it enables the research to have a qualitative understanding of a participants' life. This was particularly important as issues of health require confidentiality and sensitivity. As a result, the researcher sought to establish close relationships with the study participants to access valuable information relating to their understanding of health, as well as the choices that they have made in their quest for well-being.

From the knowledge gathered through both the field work and the literature study, key themes were drawn out, explored and presented as useful resources for constructing a relevant and contextual life-giving and life-enhancing Karanga understanding of utano ('health and well-being') in contemporary Zimbabwe. The common themes emerging from the case studies of healthcare providers and healthseekers, offer insights for constructing a Karanga indigenous understanding of health and well-being. Having explicated the background to the study and the research methodology adopted, the article proceeds to briefly present the various developmental phases in Zimbabwe to illustrate how these have impacted on Zimbabwean people's health and wellbeing.

\section{The precolonial period (1000-1889) up to the colonial period (1890-1979)}

For a period of about 1000 years, the Bushmen or San people occupied most of southern Africa, including Zimbabwe, living in a lush, well-watered but isolated Eden where game was plentiful and the trees produced fruits in abundance (Hill 2003). During this period (1000-1889), there was apparently not much biomedical medicine available; the people relied heavily on traditional herbs and traditional medicine. There was little contact with the outside world, which later introduced modern medicine and modern healthcare institutions. There was however contact between the Shona people and Arab traders as early as 1400, and by the mid-1800s several white hunters, traders and missionaries were visiting the Matebele kingdom. The coming in of missionaries, particularly the London Missionary Society and their setting up of mission stations gradually and eventually transformed the African landscape in terms of introducing educational and medical facilities (Soderstrom 1984).

Prior to the settler-colonial epoch that began in 1890, Zimbabwe experienced considerable social stability. Various Shona tributary societies and states enjoyed prosperity for centuries and by the 19th century, the strong Ndebele state had established a distinctive tradition of barter trade, partly through the influence of Portuguese, Chinese and Arab merchants (Bond \& Manyanya 2003). The land formed the basis of their production and the backbone of Zimbabwe's economy. However, the 1890 invasion by the Pioneer Column led by Cecil John Rhodes, the leader and owner of the British South Africa Company (BSAC), suddenly suddenly disrupted this social stability and impacted heavily on people's health and well-being. According to Kriger, Rhodes exploited the African people's illiteracy and made Lobengula, the king of the Matabele people in Zimbabwe, sign to sign the Rudd Concession (Kriger 1992), which was subsequently used to justify the occupation of the whole country by European settlers and take over most of the productive land. ${ }^{4}$

The colonial period had far-reaching repercussions on the majority of the Zimbabwean people's health, particularly because of their being pushed from their fertile and habitable land to areas that were not very good for human habitation, farming and livestock rearing. This historical phase can be divided into two subsections. The first is 1889-1923, known as the period during 'Company' rule, referring to the BSAC which was in control. It was during this period that most of the land appropriation occurred. This was followed by the 'Responsible Government' rule period, which ushered in the White settlers' self-governing colony from 1923 to 1952, when further appropriation of the land occurred. By 1930, most of the land was already in the hands of the invaders.

The passage of the Land Apportionment Act of 1930 divided the country into two roughly equal parts. One half was for the tiny white minority, where no black people were allowed to own property or even reside without permission; and the other half for the black original inhabitants of Zimbabwe containing the infertile and unproductive soils and receiving the lowest rainfall (Mclaughlin 1996). There were private estates throughout the country and rights of ownership were issued, despite the fact that the concept of private ownership of land was not familiar to the indigenous people of the country. Prior to the advent of the BSAC, land was in plentiful supply, people settled in an area, grazed their cattle and grew

4.Regarding the dilemma that he found himself in, Lobengula is reported to have once expressed it this way:

Have you seen a chameleon catching a fly? It approaches the fly from behind. It stands for a while. Then it moves carefully forward, lifting slowly one leg after the other. When it is close enough, it throws out its tongue and swallows the fly. England is the chameleon and I am the fly. (Hanna 1962:81) 
their crops, and moved on to fresh land when it was exhausted. They were almost all illiterate and understood neither the importance of the pieces of paper (title deeds) issued by the BSAC to white settlers, nor that they signified their own exclusion from most of the land they lived in (Farren 1993).

In the process the indigenous locals were not only disenfranchised, but they also lost their land rights. Although, during the precolonial times kings or their representatives were custodians of the land for their community because it belonged to the community, that authority was now in the hands of the Europeans (Bakare 1993). The land allocated for blacks who were much more numerous than the whites became inadequate for their requirements as their numbers increased. This led to several uprisings from the local people in an effort to reclaim their land from the BSAC. The most notable are the 1893 Matebele war and the 1896-1897 Ndebele-Shona uprisings which were both ruthlessly crushed by the power of the settlers' superior weaponry (Farren 1993). The land issue has remained a bone of contention in Zimbabwe and the main goal of the liberation struggle was to reclaim the land.

Throughout the pre-independence period (1890-1979), inadequate and inferior government provision of healthcare and education services for Africans compared with whites aroused African indignation towards the settler regime. The bulk of the government's educational and health budget was channelled towards the urban communities where the minority white population resided. Although the African councils and mission stations tried their best to provide educational and healthcare facilities in the rural areas, they could not cover the vast expanses of the rural and commercial farming communities; furthermore, they were not adequately funded by the government (Soderstrom 1984). This aroused the African ire towards the settler regime. In a bid to sabotage all the services provided by Ian Smith's regime, the guerrilla forces closed down all public facilities including the dip tanks. This had far-reaching repercussions, for instance, the closure of dip tanks is said to have reduced the national cattle herd in the tribal trust lands by up to one-third. This caused further misery for the people as their cattle became vulnerable to tick bone diseases and foot and mouth disease causing further harm to the nutrition of farmers and peasants (Kriger 1992).

There were striking disparities in income, employment, land ownership and housing between the black and white populations. Black workers' living conditions were appalling especially in the urban areas. The construction of formal apartheid-style townships formalised the already prevailing slum living conditions (Alexander, McGregor \& Ranger 2000). For instance, in the African residential areas in Salisbury, a town in which it might be said general standards were the highest in the country, less than half of those lucky enough to have homes also had electricity. Living conditions were very cramped, with most houses having three rooms or less and sustaining an average family of six at the least. In the countryside, the number of African households with access to electricity was only 2\% (Hitchens \& Stephen 1991). Running or purified water was and still is very rare. ${ }^{5}$ Wages, whether for formal or seasonal workers, were very low. As most rural populations were either cramped in tribal trust lands and some had sought refuge in urban areas, there were population explosions, leading to very high infant mortality rates. Infant mortality during this period was estimated at 122 per thousand for blacks and 17 per thousand for whites. The malnutrition rates were very alarming, mainly because Africans were packed into tribal trust lands with poor soil and little capacity for producing more than subsistence food or in the urban areas where they lacked any form of sustainable livelihood. This was the status quo on the eve of independence, such that upon attaining independence in Zimbabwe, the main focus of the country's leadership was to address these huge developmental chasms (Bond 2001).

\section{The first decade of independence (1980-1990)}

Acknowledging the fact that people are at the centre of sustainable development and that sustainable development cannot be realised in the absence of facilitating adequate and equitable healthcare services and well-being for the people, the government that came to power in 1980 invested a considerable amount of resources towards improving people's health and well-being. The government's first health policy concern was to address the link between the main health problems and poverty (Ministry of Health 1984). Primary health care was used as the main vehicle for improving healthcare provision. According to Hansson (1996), as health was linked to development, communities working with the health sector mobilised and used increased support for education, particularly female education, safe water and sanitation, better ventilated and maintained housing and improved family food production. Much emphasis was placed on preventive and simple curative care such as immunisation campaigns, environmental health and treatment of communicable diseases (TB, STIs), while primary healthcare services were subsidised. Life expectancy at birth rose from 45 years in 1960 to 60 in 1985 (Zimbabwe Human Development Report 2003).

Mobile clinics extended mother and child care to remote areas so that antenatal care reached $90 \%$ of pregnant women and more than $70 \%$ of deliveries occurred under the supervision of trained personnel. Traditional midwives were trained to perform safe deliveries, recognise complications, promote breast feeding and refer patients to the nearest health centre with the objective of reducing maternal mortality. In September 1980, free medical care was introduced for low-income groups earning less than $\mathrm{Z} \$ 150 \mathrm{a}$ month, and in November 1992 the fee exemption income was

5.This resulted in the outbreak of a cholera epidemic in late 2008 and early 2009 which killed more than 4000 Zimbabweans. The intervention of the internationa which killed more than 4000 Zimbabweans. The intervention of the international
community eventually stemmed the tide of the epidemic. However, the prevailing sanitation standards in most urban areas are still appalling. 
increased to $\mathrm{Z} \$ 400$. As a result, outpatient attendances increased dramatically (Loewenson 1998).

In addition, the Village Health Worker (VHW) ${ }^{6}$ initiated during the liberation struggle played an integral role in the building of wells and toilets, helping at clinics, organising the feeding of undernourished children and promoting food production. They (VHWs) also provided a strategic link between the patients in the villages and the medical staff at the health institutions. The VHWs were backed by a range of other community-based cadres, including community-based distributors in family-planning services, offering health education and information on sexually transmitted infections. All health services in each district, whether administered by the Ministry of Health, the district council or mission, were integrated. Together, all these interventions realised a significant improvement in general health standards and the national economic growth was at its peak during this period. However, as will be explicated below, most of the socioeconomic gains achieved during this first decade of independence were considerably eroded during the next phase (1991-2010) and this had far-reaching repercussions on people's health and well-being.

\section{The impact of Economic Structural Adjustment Programme on people's health and well-being (1991-1999)}

During this decade, Zimbabweans experienced several lifechanging socio-economic and political changes which had a significant impact on their health and well-being (see Chirongoma 2012, 2015). As the sustenance of the economy was hinged upon funding from Western financial institutions, in January 1991, the government decided to adopt the Economic Structural Adjustment Programme (ESAP), which was primarily designed by the World Bank in a bid to comply with its international funder's expectations. The changes under ESAP entailed economic privatisation, deregulation, a reduction of government expenditures on social services and deficit cutting. Measures protecting local industry from foreign competition were also withdrawn (Zimbabwe Human Development Report 2003). The adoption of ESAP and the consequent liberalisation of the economy negatively affected most people's livelihoods, especially the poor (Elich 2002). For instance, the dramatic introduction and increases of user fees caused a drastic drop in the previously stable attendance rates at the medical facilities both in the rural and urban areas (Hongoro \& Kumaranayake 2000). To add salt onto the festering wound, the introduction of user fees for rural clinics in 1992 was instituted during the worst regional drought of the century (Hongoro \& Chandiwana 1994). The increases in fertiliser prices resulted in lower yields and increased food prices forced many to reduce their food intake. The majority of the population was pushed into the doldrums of extreme poverty, and the reductions in household incomes reversed all past health gains. The erratic reductions in the health budget reduced the quality of health care, demoralised personnel in the health sector and their clients, and led people to solve their health problems in ways that are not always effective for their own health or for the long-term health of the nation. All these factors provided fertile ground for the spread of the HIV epidemic, which which became one of the leading causes of death, destroying the country's socio-economic fabric.

The other developments which had ripple effects on people's health and well-being, during this decade, include the costly involvement of the army in the Democratic Republic of Congo (DRC) where the Zimbabwean army was sent to support President Laurent Kabila against a rebellion which put a dent on the already ailing economy, the payment of gratuity to the former freedom fighters which caused the sudden crash of the local currency and the general civil unrest (see Bond \& Manyanya 2003; Hill 2003; Meldrum 2004). All these developments impacted heavily on ordinary people's capacity to afford basic commodities or to access basic healthcare services as the socio-economic and political situation continued tumbling on a downward spiral. In the process, these developments also set the scene for the eventual humanitarian crisis that was unfolded in the last decade (2000-2010), resulting in the closing of several public healthcare facilities and the closing down of most academic institutions as discussed below.

\section{Further socio-economic decline impacting the healthcare system (2000-2010)}

Social analysts such as James Bond often refer to this particular decade as 'the decade of crisis' because of the extreme poverty, suffering, destitution, demolition of most informal structures and forced immigration that were endured by so many Zimbabweans. The decade started with the infamous land invasions orchestrated by former freedom fighters and other land hungry ordinary citizens. This move pressurised the Zimbabwean government to redistribute land without compensating the white commercial farmers who owned the bulk of the fertile and productive land. Unfortunately, this brought the Zimbabwean socio-economic situation to a tipping point because the international community retaliated by withdrawing aid. Worse still, the land invasion and land redistribution processes precipitated the existing economic crisis through destroying a substantial portion of commercial agriculture, which provided $45 \%$ of the country's foreign exchange revenue and livelihood for more than $70 \%$ of the population. There was also a steep decline in foreign earnings, and food shortages were intensified. All these developments exerted massive pressure within the health sector, which was already choking because of increased burden of diseases, particularly the increasing numbers of HIV- and AIDS-related illnesses and deaths.

The government's decision to undertake the infamous 'Operation Murambatsvina/Operation Clean Up' in July 2005 
causing the destruction of many informal business structures and the demolition of several people's homes also posed a further strain on the already battling economy and weak public healthcare system. By 2005, Zimbabwe was reported to have the world's fourth-highest rate of HIV prevalence. Primary clinics and district hospitals did not provide medicine for HIV- and AIDS-related illnesses, and patients had to travel to larger towns to access such treatment (Chirongoma 2006).

The period between 2006 and 2008 was the worst in terms of the humanitarian crisis. Faced with empty coffers, a fast crumbling health delivery system, isolation from the international community and shortages in medical aid scheme benefits, some patients were left to suffer with no relief in sight. The main referral hospitals in the country Harare Central Hospital and Parirenyatwa Hospital in Harare and Mpilo Hospital and United Bulawayo Hospitals in Bulawayo - were virtually closed for the larger part of 2008. And most district hospitals and municipal clinics were barely functioning or closed. Sick people in need of medical attention were being turned away from Zimbabwe's public hospitals and clinics; they were advised to consult private doctors in private facilities. However, this option was not open to the majority of Zimbabweans already struggling to make ends meet (Machinga 2011).

It is against this backdrop of socio-economic and political turmoil that one would be tempted to conclude that the Zimbabwean people folded their arms and hopelessly faced their imminent death. To the contrary, it was during this decade of crisis that most ordinary Zimbabweans unleashed their innovation, tenacity and resilience by taking charge of their health and well-being through what some development specialists would consider 'unconventional' ways of preserving and sustaining health and well-being. It was particularly during this period that Zimbabwe experienced a mushrooming of faith-healing ministries and a revival of the traditional healers associations playing a fundamental role in catering for ordinary people's health and well-being. Although, it was during this period that several Zimbabweans joined the exodus movement seeking for greener pastures in the Diaspora, more than three quarters persevered and remained in the country, taking charge of their lives through utilising multiple healthcare systems such as faith-healers and traditional healers whenever the need arose.

In view of the fact that the public healthcare system is still struggling to revive some of its structures in its quest to provide adequate, equitable and holistic care to the citizens of Zimbabwe even during the time of the writing of this article (March, 2016), the agency and innovativeness of the ordinary people, particularly the majority of the population in the rural communities, should be appreciated. This will be explicated below through an exploration of themes emerging from insights shared by study participants reflecting on their health-seeking and health provision endeavours in the face of a troubled, unstable and volatile socio-economic and political landscape.

\section{Acknowledging the agency of health seekers}

Utano is achieved when, on the basis of indigenous beliefs and Christian beliefs regarding health, individuals and families invest in refusing to accept ill-health. Participants in the study demonstrated how they sought the opinions of traditional healers, prophet healers and modern health practitioners whenever they felt that their condition was compromised. They did not wait to die at home or embrace some fatalistic theology. In fact, they took their own destiny into their own hands and tried out the various health delivery systems in search of health and healing. Even the reality of HIV and AIDS did not create a culture of despondency. It is this positive philosophy of life that empowers individuals to seek the services of traditional healers, prophet healers or services from clinics. Utano is sought after and when achieved, must be preserved. Individuals exercise their agency to achieve this goal.

A Karanga understanding of utano which prioritises the agency of the health seekers is built on two main foundations: the Bible's emphasis on the integrity of human beings and the indigenous sayings that promote initiative. The Bible contends that human beings are created in the image of God (Gn 1:27). All human beings, therefore, must be treated with the utmost respect. They possess divine attributes and must be respected. A Karanga understanding of utano respects this basic tenet. It challenges interpretative systems that promote the views of outsiders and insists on respecting the point of view of the individual Karanga men and women when they make their health choices.

In order to facilitate a progressive Karanga understanding of utano which acknowledges the agency of health seekers, it is important to embrace postcolonial readings of the Bible (Dube, Mbuvi \& Mbuwayesango 2012). Such interpretations of the Bible promote the total liberation of Africans from colonial and colonising interpretations of the text. This is urgent in developing indigenous theologies, such as the Karanga understanding of utano, as the colonial project tended to project negative images of Africans. As some of the interviews showed, some converts to Christianity now have a totally negative attitude towards indigenous health delivery systems. By embracing postcolonial biblical interpretation, the Karanga understanding of utano will reinterpret biblical passages that have been used to demonise traditional healing systems.

As the research participants revealed, individuals and communities are determined to access health and healing. However, sometimes the Bible is used to promote fatalistic theologies. Some individuals have been discouraged from seeking treatment, especially in the context of HIV and AIDS. Adopting creative biblical interpretations and oral theology can empower individuals and families to embrace life-giving perspectives on health and healing. They need to do this in dialogue with an integrated approach to health delivery. 
A viable Karanga understanding of utano must appreciate that the three health delivery systems are complementary. They must not be regarded as competitors, but each one of them addresses specific needs at specific times. The participants clearly indicated that the Karanga people move back and forth and across the three health delivery systems. Health seekers and healthcare providers indicated that there is a lot of diagnosis that takes place prior to making a decision as to which particular system to approach. The participants clearly stated that when individuals and families are convinced that a particular form of sickness is spiritual, they resort to traditional healers and prophet healers. On the other hand, if they contend that an illness is 'natural', they go to a clinic. However, what might start off as 'natural' may later be considered spiritual and the choice of health service provider will be changed accordingly. Such responses to forces that threaten health and well-being are also influenced by the Karanga health worlds.

In order to avoid the emotional trauma suffered by individuals who attend theologically conservative churches such as the Seventh-Day Adventist Church and several other Pentecostal churches, it is vital for a Karanga theology of utano to have an integrated approach towards the health delivery systems. As Stuart Bates argues, there is an urgent need for churches to appreciate the need for 'coping healing' in Africa (Bate 1995). Churches would have failed in their pastoral ministry when individuals and families are forced to consult other health delivery systems under the cover of darkness because of the fear of censure. Effective pastoral work requires an open and accommodating approach to the burning issues of the day. All the theologically conservative churches should be challenged to embrace the three health delivery systems as critical components of God's plan of healing.

An attractive and effective Karanga understanding of utano requires theological creativity in the face of the three health delivery systems. Old positions and formulae will not equip the people of God to navigate new contexts. Churches run the risk of becoming irrelevant if they do not meet the needs of the people. The study participants revealed the struggles and anxieties that characterise the Karanga people's search for health and well-being. A Karanga theology of utano requires that churches 'accompany ${ }^{\prime 7}$ individuals and families by affirming their choices, rather than condemning nonWestern approaches to health delivery. Writing in the context of caring in the HIV era, Ezra Chitando was reminded of the ubuntu virtues among the Shona people, where:

$\ldots$ visitors are to be treated with utmost courtesy. When visitors announce their departure, hosts are expected to try to persuade them to stay. When visitors leave, hosts are expected to see them out of the homestead. More importantly, they are also expected to travel with them for a good part of the journey. Kuperekedza (to accompany) implies identifying with the person undertaking the journey. In effect, they are told, 'You are not alone on this journey. I share your struggle'. (Chitando 2007:2)

7.1 am indebted to Ezra Chitando for the concept, 'theology of accompaniment' (Chitando 2007).
In the same light, churches should be willing to 'accompany' health seekers in their quest for health and well-being, assuring them that 'they are not alone' and that they have the support and approval of the church even though their search might require utilising multiple healthcare systems. By adopting an integrated approach, a Karanga understanding of utano can equip individuals, families and communities to tap the strengths of the different health delivery systems. Instead of demonising traditional healers and other prophet healers, churches must be more creative and consider these as part of God's grand healing plan. At any rate, if the capacity to heal ultimately derives from the same sacred source, it is permissible to accept healing from traditional healers and prophet healers. Only divinely ordained healers can avail health and well-being. Consequently, all such healers need to be accepted as working on behalf of the God of health and healing. A Karanga theology of utano, therefore, must have an expansive and integrated view of the different healthcare systems. This is confirmed by Gurli Hansson (1996:35) when she says:

Recently there has grown (sic) a closer understanding between the two medical systems, where the modern scientific system begins to appreciate the traditional medical knowledge and not least the holistic view of the patient and his/her illness. (p. 35)

A Karanga understanding of utano recognises the reality of religious pluralism in Africa (Olupona \& Nyang 1993). Such a perspective is informed by the biblical view that the earth and everything in it was created by God (Ps 24:1). It is also based on the idea that one cannot classify as unclean that which was created by God (Ac 10:15). These concepts from the Bible can be appropriated to empower Karanga Christians to eliminate negative attitudes towards competing health delivery systems. An integrated approach to health and healing enables individuals and families to appreciate the fact that at the heart of all the systems is the quest to support life. Health practitioners from the diverse health systems must be seen as agents of God. By adopting such a holistic perspective, individuals and communities can embrace a more holistic perspective. According to James Cochrane (201):

Healthy bodies are signs of blessing or religious favour, of the impulse to life in the face of much that threatens it. This is one way of recognising why and how healing is not only an expression of faith or a tradition but equally a mark of selfunderstanding in African traditional religions, African Christianities (e.g. the African Independent Churches, or, for much longer, the Coptic Church), Islam in its basic doctrines, and other less prominent religious traditions of Africa. All invoke not merely healing of the body but of relationships and the spirit, however variously defined. (p. 438)

\section{Conclusion}

An understanding of healing must include a creative rereading of biblical stories such as the raising of Lazarus (Jn 11:1-42). In this story, Jesus demonstrates that his ministry was essentially about defeating death and promoting life. Church leaders, theologians and activists must formulate a 
theology that challenges health delivery systems that deliver death, not life. This was the situation in Zimbabwe between 2000 and 2008. Through literature study and information provided by study participants, this article has shown how clinics and hospitals ran out of essential drugs and qualified personnel. According to Emmanuel Katongole (2012:30):

That is why a theological engagement committed to resurrection in Africa must seek to awaken Africa out of its slumbering tombs; it must engage the conditions that contribute to the drowsy, often half-awake condition that keeps many Africans entombed in poverty and other forms of bondage. (p. 30)

Systems of death must be confronted as they prevent the Karanga from enjoying health and wellness. They stifle individuals and communities from achieving their full potential. Stories from indigenous communities emphasise the need to uphold life in the face of many threats. These indigenous approaches to health and healing challenge poverty and promote a theology of healing and liberation. Moreover, the Karanga people privilege the community; there are webs of relationships that bind individuals to their families and communities. In this regard, ukama ['relatedness'] is tied to utano. ${ }^{8} \mathrm{An}$ individual's health is not limited to his or her physical status. Instead, it extends to how she or he relates to other members of the family and the community (Murove 2004).

A Karanga understanding of utano needs to embrace the communal orientation that forms the bedrock of both the community and the church. The notion of hunhu/ubuntu [I am because we are] runs through both the community and the church. Individual autonomy does not receive emphasis ahead of the sense of belonging. This is why health issues are not exclusive affairs. Other members of the family are involved in the diagnosis and therapy. Utilising indigenous wisdom and Christian concepts is helpful in constructing the Karanga understanding of utano which appreciates the value of the community. Proverbs such as 'munhu munhu haaenzani nembwa' (a person is a person, he or she cannot be compared to a dog) and 'murombo munhu' (a poor person is also a human being) confirm the emphasis on upholding the rights of all persons in the community (Chimuka 2001). No individual should be allowed to die because of his or her economic status. The community must come together to rescue that particular individual, because his or her economic status does not define his or her humanity. The community plays a key role in determining an individual's future.

Christian teachings, especially in their Protestant and Pentecostal versions, have placed too much emphasis on individual salvation. This has led some Karanga people to worry exclusively about their own health. They no longer subscribe to the communal approach to health and healing. Such an approach overlooks the injunction to 'carry each other's burdens' (Gl 6:2). The church, like the community in indigenous African wisdom, stands as a community of those who care for one another. It must be characterised by solidarity and concern for the poor and the vulnerable. Where the traditional system had the king or chief looking after the welfare of the entire community in a representative capacity, the church too is invited to support the Karanga people as they search for health and healing.

\section{Acknowledgements Competing interests}

The authors declare that they have no financial or personal relationships which may have inappropriately influenced them in writing this article.

\section{References}

African Religious Health Assets Programme (ARHAP), 2006, Appreciating assets: The contribution of religion to universal access in Africa, Report for the World Health Organization, African Religious Health Assets Programme, Cape Town.

Alexander, J., McGregor, A. \& Ranger, T., 2000, Violence and memory: One hundred years in the 'dark forest' of Matebeleland, James Currey, Oxford.

Bakare, S., 1993, My right to land in the Bible and in Zimbabwe, Zimbabwe Council of Churches, Harare.

Bate, S.C., 1995, Inculturation and healing: Coping-healing in South African Christianity, Cluster Publications, Pietermaritzburg.

Bond, P., 2001, 'Radical rhetoric and the working class during Zimbabwean nationalism's dying days', Journal of World Systems Research 17(1), 52-89.

Bond, P. \& Manyanya, M., 2003, Zimbabwe's plunge: Exhausted nationalism, neoliberalism and the search for social justice, University of Natal Press, Pietermaritzburg.

Casey, A., 2011, 'The use and limitations of oral tradition in the New Testament and the implications for theology in oral contexts today', viewed 20 August 2012, from http://culturnicity.files.wordpress.com/2011/04/sufficiency-of-oral-theologypost.pdf

Chimuka, T.A., 2001, 'Ethics among the Shona', Zambezia 28(1), 23-37.

Chirongoma, S., 2006, 'Women, poverty and HIV in Zimbabwe: An exploration of inequalities in health care', in I.A. Phiri \& S. Nadar (eds.), Women, religion and health: Essays in honour of Mercy Amba Ewudziwa Oduyoye, pp. 173-182, Orbis Bealth: Essays in honour

Chirongoma, S., 2012, 'In search of a sanctuary: Zimbabwean migrants in South Africa', in J. Carpenter (ed.), Walking together: Christian thinking and public life in South Africa, pp. 150-175, ACU Press, Abilene, TX.

Chirongoma, S., 2015, 'An exploration of how the Third Chimurenga impacted on the national health-care delivery system in Zimbabwe', in V. Nyawo (ed.), Repositioning the Humanities: Journal of Contemporary Research, vol. 2(1), pp. 135-158, Midlands State University, Gweru.

Chitando, E., 2007, Living in hope: African churches and HIV/AIDS 2, WCC Publications, Geneva.

Cochrane, J.R., 2012, 'Religion, health, and the economy', in E.K. Bongmba (ed.), The Wiley-Blackwell companion to African religions, pp. 430-442, 438, Blackwell, Oxford, West Sussex.

De Gruchy, S., 2003, 'Of agency, assets and appreciation: Theological themes for social development', Journal of Theology for Southern Africa 117(2), 20-39.

Dhunpath, R. \& Samuel, M., 2009, 'Introduction', in R. Dhunpath \& M. Samuel (eds.), Epistemology methodology and representation, pp. i-xiv, Sense Publishers, Rotterdam.

Dube, M.W., Mbuvi, A. \& Mbuwayesango, D. (eds.), 2012, Postcolonial perspectives in African Biblical interpretations, Society for Biblical Literature, Atlanta, GA.

Ela, J.M., 1989, African cry, Orbis Books, New York.

Elich, G., 2002, 'Swans commentary: Zimbabwe under siege', 26 August, viewed 18 March 2004, from www.swans.com/library/art/elich004a.html

Farren, L., 1993, 'This land is my land?', in S. Bakare (ed.), My right to land in the Bible and in Zimbabwe, pp. 65-79, Zimbabwe Council of Churches, Harare.

Gunderson, G.R., 1998, Aligning assets for community health improvement: Building on enduring strengths of faith groups and health sciences, Fortress Press, Minneapolis, MN.

Hanna, A.J., 1962, The story of Rhodesia and Nyasaland, Johnson, London.

Hansson, G., 1996, Mwana Ndi Mai: Toward an understanding of preparation for motherhood and child care in the transitional Mberengwa district, Zimbabwe, Studia Missionalia Upsalieansia, no. LXV, Swedish Institute of Missionary Research, Uppsala.

Hill, G., 2003, The battle for Zimbabwe: The final countdown, Struik Publishers, Cape Town.

Hitchens, C. \& Stephen, D., 1991, Inequalities in Zimbabwe, Report No. 8, Minority Rights Group, London. 
Hongoro, C. \& Chandiwana, S., 1994, 'Effects of user fees and health care in Zimbabwe', Blair Research Institute, Harare.

Hongoro, C. \& Kumaranayake, L., 2000, 'Do they work? Regulating for-profit providers in Zimbabwe', in Health policy and planning, vol. 15(4), pp. 368-377, Oxford University Press, Oxford.

Kakuru, D.M. \& Paradza, G., 2007, 'Reflection on the use of life history method in researching rural African women: Field experiences from Uganda and Zimbabwe', Gender and Development 15(12), 287-297. http://dx.doi.org/10.1080/135520 70701391581

Katongole, E., 2012, 'The raising of Lazarus and the sites for African theological exploration and engagement', in A.J. Bwangatto (ed.), Africa is not destined to die: Signs of hope and renewal, pp. 21-32, Paulines Publications Africa, Nairobi.

Kretzmann, J. \& McKnight, J.L., 1993, Building communities from the inside out: A path toward finding and mobilizing a community's assets, ACTA Publications, Chicago, IL.

Kretzmann, J. \& McKnight, J.L., 2002, Assets-based strategies for faith communities, Asset-Based Community Development Institute of Northwestern University, Chicago, IL.

Kriger, N.J., 1992, Zimbabwe's Guerrilla War: Peasant voices, Cambridge University Press, Cambridge.

Loewenson, R., 1998, Health in Zimbabwe: Community perspectives, TARSC Monograph/98, Ministry of Health and Child Welfare, Harare.

Machinga, M., 2011, 'Religion, health, and healing in the traditional Shona culture of Zimbabwe', Practical Matters 4, 1-8.

Manda, D.L., 2006, South African women's health with specific reference to HIV/AIDS. An ethical enquiry into the importance of the African ethic of Ubuntu and traditional African healing systems in a search for psychosocial and spiritual wellbeing, Unpublished PhD thesis, University of KwaZulu-Natal, Pietermaritzburg.

McLaughlin, J., 1996, On the frontline: Catholic missions in Zimbabwe's Liberation War, Baobab Books, Harare.

Meldrum, A., 2004, Where we have hope: A memoir of Zimbabwe, Murray Publishers, London, Great Britain.
Ministry of Health, 1984, Planning for equity in health, Government Printers, Harare. Murove, M.F., 2004, 'An African commitment to ecological conservation: The Shona concepts of Ukama and Ubuntu', The Mankind Quarterly 45(2), 195-215.

Murove, M.F., 2005, 'The theory of self-interest in modern economic discourse: A critical study in light of African humanism and process philosophical anthropology', Unpublished PhD thesis, University of South Africa.

Murove, M.F., 2007, 'The Shona ethic of Ukama with reference to the immortality of values', Mankind Quarterly 48(2), 179-189.

Murove, M.F., 2009, 'An African environmental ethic based on the concepts of Ukama and Ubuntu', in M.F. Murove (ed.), African ethics: An anthology of comparative
and applied ethics, pp. 157-177, University of KwaZulu-Natal Press, Pietermaritzburg.

Naudé, P., 1996, 'Theology with a new voice? The case for an oral theology in the South African context', Journal of Theology for Southern Africa 94(23), 18-30.

Olupona, J.K. \& Nyang, S.S. (eds.), 1993, Religious plurality in Africa: Essays in honour of John S. Mbiti, Gruyter, Berlin.

Samkange, S. \& Samkange, T.M., 1980, Hunhuism or Ubuntuism: A Zimbabwe indigenous political philosophy, Graham Publishing, Salisbury.

Samuel, M., 2009, 'On becoming a teacher: Life history research and force-field model in teacher development', in R. Dhunpath R \& M. Samuel (eds.), Epistemology, methodology and representation, pp. 3-18, Sense Publishers, Rotterdam.

Shoko, T., 2007, Karanga indigenous religion in Zimbabwe: Health and well-being, Ashgate Publishing Limited, Aldershot.

Soderstrom, H., 1984, God gave growth: The history of the Lutheran Church in Zimbabwe 1903-1980, Mambo Press, Gweru.

Thomas, L., Schmidt, B., Gwele, M., Ngubo, R. \& Cochrane, J.R., 2006, Let us embrace The role and significance of an integrated faith-based initiative for HIV and AIDS, African Religious Health Assets Programme (ARHAP), Cape Town.

Zimbabwe Human Development Report, 2003, Redirecting our responses to HIV and AIDS: Towards reducing vulnerability-the ultimate war for survival, University of Zimbabwe Publications, Harare. 